Proc. Estonian Acad. Sci. Eng., 2006, 12, 2, 125-133

\title{
Mechanical properties of pinewood (Pinus Sylvestris) swollen in organic liquids
}

\author{
Pille Meier ${ }^{\mathrm{a}}$, Eve Stöör ${ }^{\mathrm{a}}$, Tiit Kaps ${ }^{\mathrm{a}}$ and Urve Kallavus ${ }^{\mathrm{b}}$ \\ a Department of Polymer Materials, Tallinn University of Technology, Ehitajate tee 5, 19086 Tallinn, \\ Estonia; meier@cc.ttu.ee \\ b Centre for Materials Research, Tallinn University of Technology, Ehitajate tee 5, 19086 Tallinn, \\ Estonia
}

Received 8 November 2005, in revised form 20 February 2006

\begin{abstract}
The aim of this research was to determine the mechanical properties of pinewood, swollen in water and aqueous solutions of ethanol and acetone. For this purpose, pine sapwood specimens were swollen in water, ethanol, acetone and aqueous solutions of ethanol and acetone. Static bending and compression strength along the grain and deflection in bending were determined. The results of this study show that a strong correlation exists between the strength properties and the swelling degree of pine sapwood. Pure substances and aqueous solutions influenced the mechanical properties of wood in different ways. Pine sapwood, swollen in aqueous solutions of ethanol, has better elastic properties compared to wood, swollen in other organic liquids used in this study.
\end{abstract}

Key words: pinewood, swelling, organic liquid, strength, deflection.

\section{INTRODUCTION}

Wood is a hydrophilic material, very sensitive to water and other liquids. The changes in the H-bonding system, caused by the liquids uptake by the cell wall, usually leads to changes in the physical and mechanical properties of wood $\left[{ }^{1-4}\right]$.

In previous studies $\left[{ }^{5,6}\right]$ it was found that wood swells in aqueous solutions of some organic liquids more than in water or pure liquids. The influence of hyperswelling on wood material and its properties is not known yet. One possible way to explain the phenomenon of hyperswelling is to investigate physical and mechanical properties of swollen wood.

It is known that strong relation exists between the strength of the wood and the moisture content (MC) below the fibre saturation point (FSP). Small clear 
specimens of wood in an air-dry condition $(\mathrm{MC}=12 \%)$ have practically twice the strength in bending and compression of the same material when unseasoned, while in kiln-dried $(\mathrm{MC}=5 \%)$ wood the increase in strength may be threefold $\left.{ }^{2,4}\right]$. When the moisture content is above the FSP, the changes in mechanical properties are inconsiderable.

Besides the moisture content, other factors as the wood structure, size of samples, direction of testing and testing criterions affect mechanical properties of wood $\left[{ }^{7-12}\right]$. The aim of the present study was to investigate mechanical properties of pine sapwood swollen in water, ethanol, acetone and aqueous solutions. The mechanical properties of wood at moisture content below FSP have been already intensively investigated. The influence of different organic liquids on mechanical properties of wood, especially measured in the maximum saturated condition of wood, would give additional information for clarifying the phenomenon of hyperswelling.

\section{EXPERIMENTAL}

\subsection{Materials}

Sapwood samples of pine (Pinus Sylvestris) for this investigation were selected with clear grains and free from defects. The samples were cut from green wood in three different forms:

- $20 \times 20 \times 10 \mathrm{~mm}$ (radial $\times$ tangential $\times$ longitudinal), for the swelling test (altogether 130 specimens);

- $10 \times 10 \times 200 \mathrm{~mm}$, for the static bending test (altogether 300 specimens);

- $20 \times 20 \times 30 \mathrm{~mm}$, for the compression strength test (altogether 300 specimens).

All samples were oven dried at $103^{\circ} \mathrm{C}$ to constant weight. The density of pinewood varied from 0.4 to $0.55 \mathrm{~g} / \mathrm{cm}^{3}$ and the number of annual rings per $\mathrm{cm}$ was from 8 to 10 in the oven-dried condition.

Liquids used in this study were distilled water (Wt), pure acetone (Act) and 96\% ethanol (EtOH). The aqueous solutions of organic solvents for the swelling test were prepared in different concentrations with 0.2-0.9 molar fractions (MF). For the static bending and compression tests the aqueous solutions were prepared only in the concentration of $0.5 \mathrm{MF}$.

\subsection{Methods}

\subsubsection{Swelling test}

The samples of pinewood were prepared as described above for the treatment with liquids - water, organic solvents and aqueous solutions of these solvents at different concentrations. All experiments were performed at room temperature $\left(20^{\circ} \mathrm{C}\right)$. All dimensional measurements were made with a Vernier caliper of accuracy $\pm 0.05 \mathrm{~mm}$. The radial and tangential dimensions were measured as quickly as possible (to avoid humidity uptake from the air) and samples were 
immediately immersed in the swelling agents and the containers sealed. The swelling and mechanical properties of wood were determined after 90 days $\left[{ }^{5}\right]$.

\subsubsection{Static bending and compression tests}

A testing machine for materials was used for the static bending and compression tests. The static bending test was performed in the tangential direction of wood fibres under the following conditions: span $90 \mathrm{~mm}$ of central loading and down-speed of the cross-head $10 \mathrm{~mm} / \mathrm{min}$. The tests were stopped when the samples started to break. The bending and compression strengths were calculated using conventional methods $\left[{ }^{4}\right]$.

For calculating the bending strength, the following equation was used $\left[{ }^{4}\right]$ :

$$
\sigma_{\text {bend.str. }}=\frac{3 F_{\max } L}{2 b h^{2}}
$$

where $\sigma_{\text {bend.str. }}$ is the bending strength, $F$ is the maximum force, $L$ is the space between two supports, $b$ is the width of the sample and $h$ is the thickness of the sample.

The compression test was performed in the longitudinal direction of wood with down-speed $10 \mathrm{~mm} / \mathrm{min}$. The tests were stopped when the samples started to break. For calculating the compression strength $\sigma_{\text {comp.str. }}$ the following equation was used $\left[{ }^{4}\right]$ :

$$
\sigma_{\text {comp.str. }}=\frac{F}{a b}
$$

where $a$ and $b$ are the cross-sectional dimensions of the sample.

Investigation of the cell wall structure was carried out with the scanning electron microscope JEOL JSM 840A at $\left.15 \mathrm{kV} \mathrm{[}{ }^{5}\right]$.

\section{RESULTS AND DISCUSSION}

Wood is an anisotropic material and all physical and mechanical properties must be determined in radial, tangential and longitudinal directions. The bending tests were performed in tangential direction and therefore the tangential swelling of wood was measured. The compression test was performed in longitudinal direction and the cross-sectional swelling (radial and tangential directions) of wood was measured. The results of the swelling tests confirmed previous results $\left[{ }^{5,6}\right]$ and showed that pine sapwood swells in aqueous solutions more than in water, acetone and ethanol. The synergistic effect in swelling was observed in the cross-sectional area in the tangential direction (Figs. 1 and 2). There are some similarities between the ethanol and acetone swelling curves. Both organic solvents swell wood less than water. 


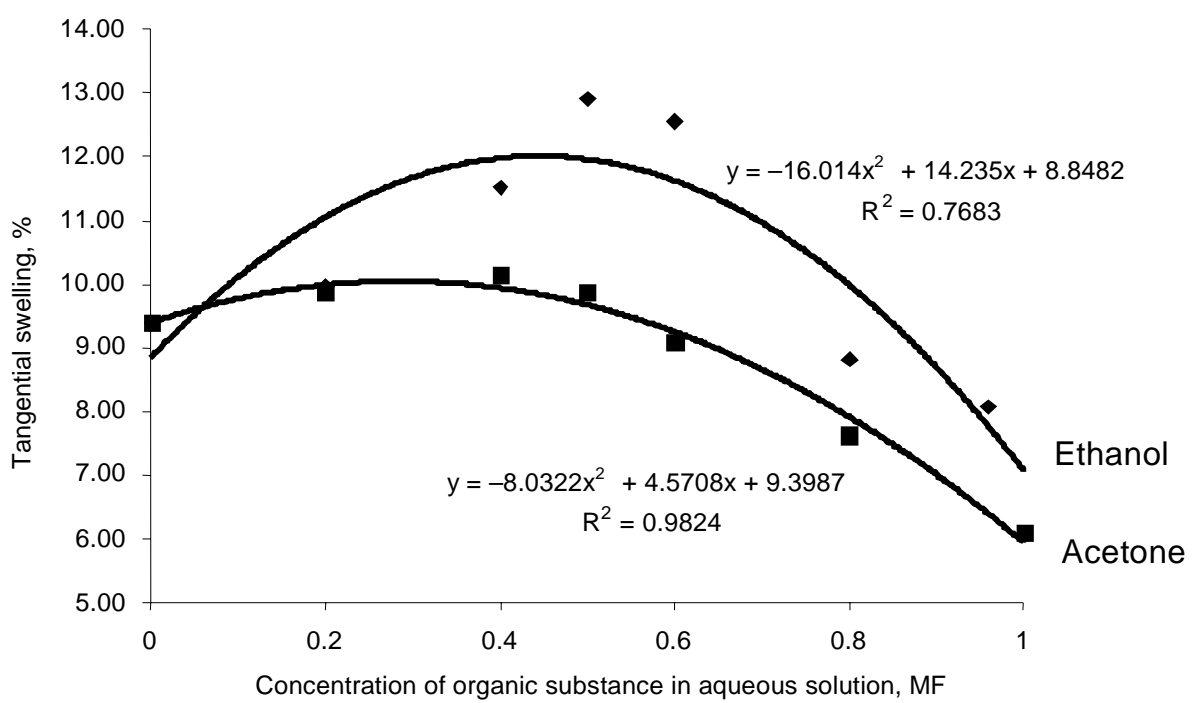

Fig. 1. Tangential swelling of pinewood in aqueous solutions of ethanol and acetone.

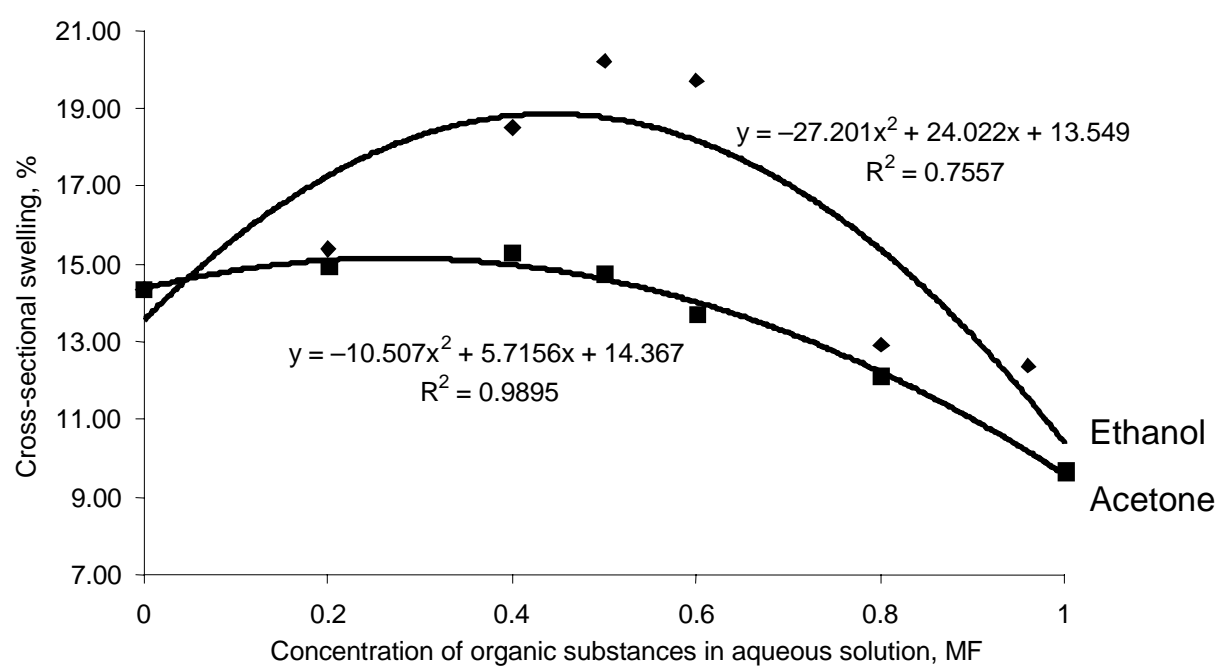

Fig. 2. Cross-sectional swelling of pinewood in aqueous solutions of ethanol and acetone.

The fibrous nature of wood strongly influences its mechanical properties. Wood is primarily composed of hollow, elongated spindle-shaped cells that are arranged parallel to each other along the trunk of the tree. When timber and other products are cut from the tree, the characteristics of these fibrous cells and their arrangement affect such properties of wood as swelling, shrinking, strength and elasticity. 
In this study, the bending and compression strength parallel to the grain of swollen wood were determined. Both properties are important from a practical point of view, for example in building constructions and by producing bentwood, laminated bend, shaped plywood, etc.

It is well known that changes in the moisture content below the fibre saturation point has very strong influence on the strength properties of wood $\left[{ }^{2,7}\right]$. When MC is above FSP, the strength properties do not change significantly. The fact that different liquids have different swelling abilities is also common knowledge and the swelling abilities mostly depend on the size of the molecules of the swelling liquids. The liquids used in this study have different swelling rates. As we have observed in our previous studies, all these liquids swell pine sapwood in 90 days to the maximum saturated condition.

The goal of the study was not to determine the absolute values of mechanical properties, but to compare the influence of different liquids on the strength of wood. Therefore all experiments were carried out in the same conditions. Both, static bending strength and compression strength along the grain of swollen pine sapwood appeared to be strongly related to the swelling of wood (Figs. 3, 4). The deflection in the static bending test was also measured (Fig. 5). A strong correlation exists between the tangential swelling of wood and its deflection.

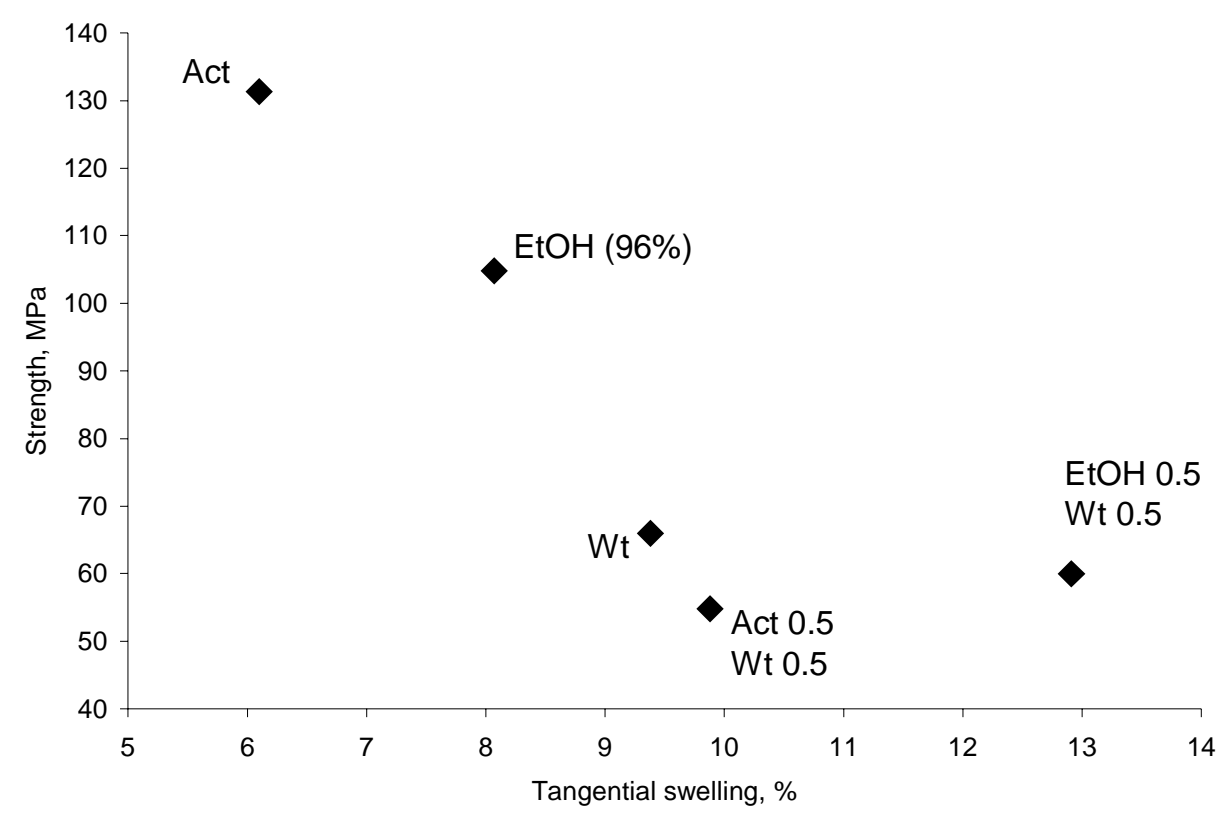

Fig. 3. Bending strength in tangential direction as a function of the percentage of swelling and of the liquid. 


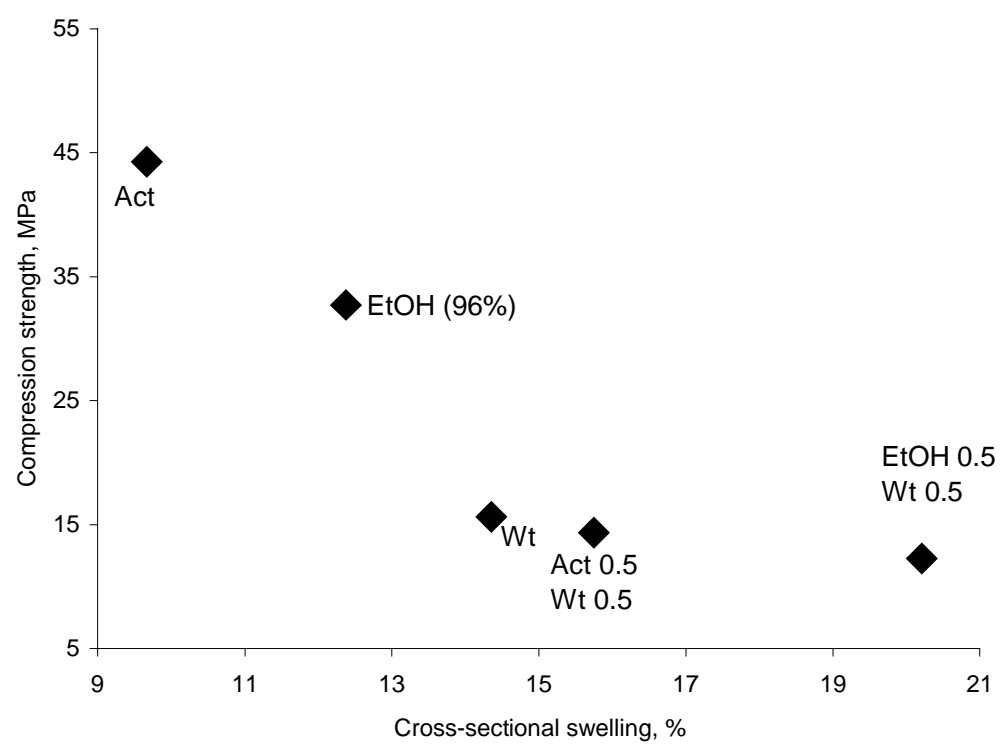

Fig. 4. Compression strength parallel to the grain as a function of the percentage of cross-sectional swelling and of the liquid.

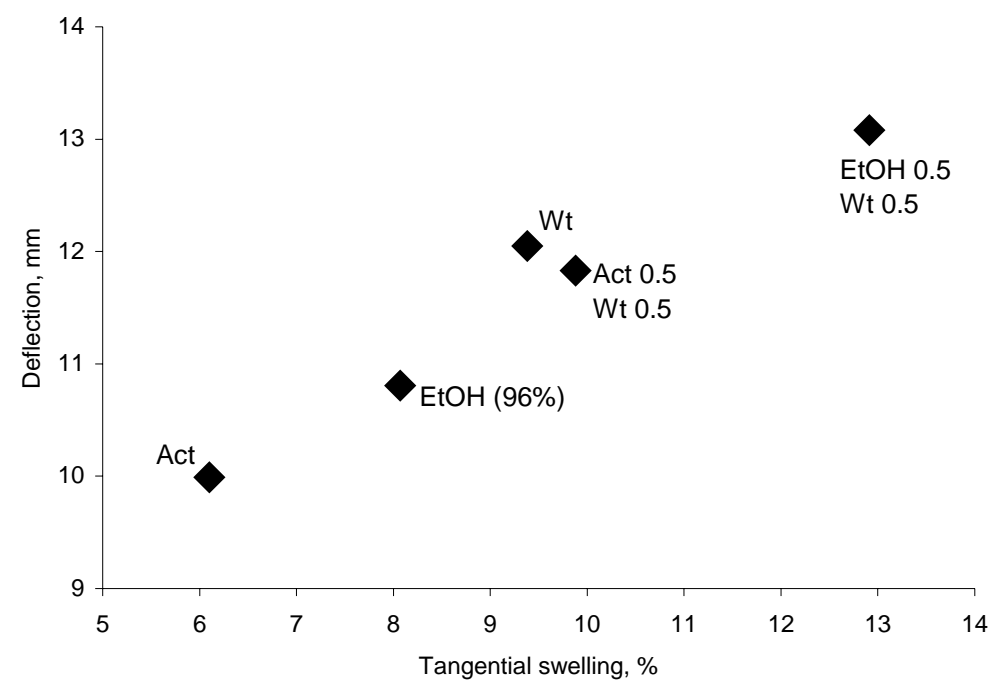

Fig. 5. Deflection as a function of the percentage of tangential swelling and of the liquid.

SEM micrographs of swollen wood [ $\left.{ }^{5}\right]$ showed that liquids, used in this study, influenced the cell wall structure in different ways. The cells, swollen in water, were densely packed and the CML was arranged in a form of continuous ribbon around the cell (Fig. 6). 


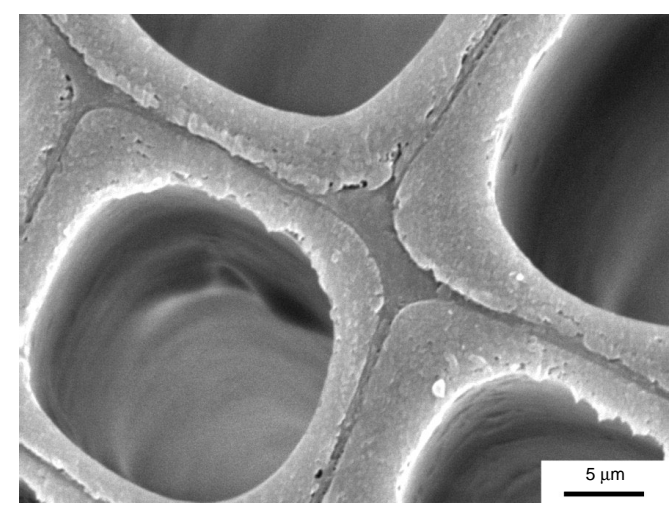

Fig. 6. SEM micrographs of pine sapwood, swollen in water $\left[{ }^{5}\right]$.

Acetone and acetone-water mixture had a very mild effect on the cell wall structure and its bonding to the CML (Fig. 7).

The most significant changes in the wood cell structures occurred in the case of interaction between wood and aqueous solutions of ethanol (Fig. 8).

Swelling of wood in ethanol (96\%) already caused the weakening of bonds between compound middle lamellae (CML) and S1 layer. Ethanol-water mixture at molar fraction 0.5 had greater influence on the structure of wood - the wood cells were separated from each other and CML was hanging between the detached cells. The ethanol-water mixtures apparently dissolved the main part of lignin in CML and released individual cells at sectioning. That kind of changes in the cell wall structure explain also the specific mechanical behaviour of pinewood, swollen in ethanol-water mixtures. As the strength properties of wood mainly depend on the cell wall S2 layer, which is not affected by liquids, the

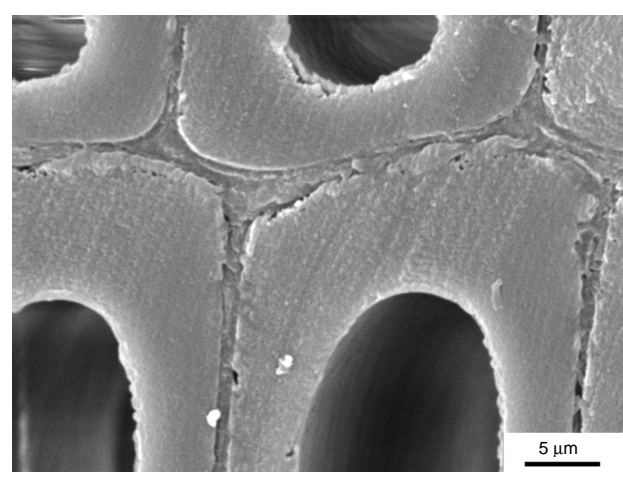

(a)

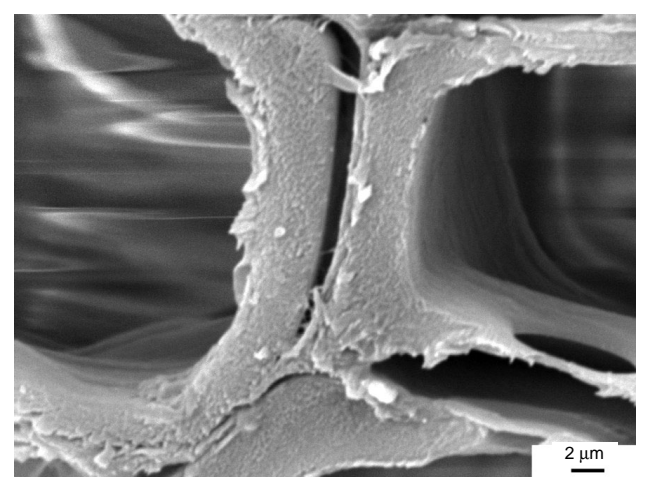

(b)

Fig. 7. SEM micrographs of pine sapwood, swollen in acetone (a) and in the acetone aqueous solution at molar fraction of Act $0.5(\mathrm{~b})\left[^{5}\right]$. 


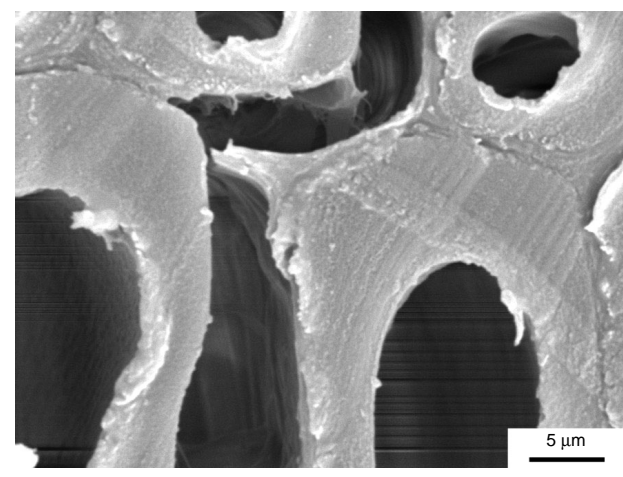

(a)

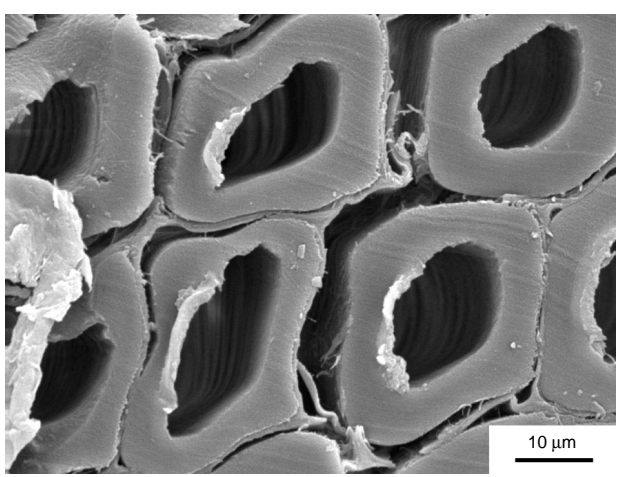

(b)

Fig. 8. SEM micrographs of pine sapwood swollen in $96 \%$ ethanol (a) and ethanol aqueous solution at molar fraction of EtOH 0.5 (b) $\left[^{5}\right]$.

static bending and compression strength (Figs. 3, 4) values of pinewood, swollen in water and aqueous solutions, are comparable. Most significant changes after swelling in ethanol-water mixtures took place in CML, which mostly consist of lignin $(80 \%)$, and therefore are causing better elastic properties of wood.

\section{CONCLUSIONS}

We have established that a strong correlation exists between the strength properties and swelling degree of pine sapwood. The results show that most intensive swelling takes place by using organic substances in aqueous solutions, but at the same time the strength is decreased to about the same amount than by using only water. Pine sapwood, swollen in aqueous solutions of ethanol, has better elastic properties compared to the wood, swollen in other liquids used in this study. Further quantitative studies about the relationship between the swelling degree and the strength properties of wood, swollen in different liquids, are needed.

\section{REFERENCES}

1. Mantanis, G. I., Young, R. A. and Rowell, R. M. Swelling of wood, I: Swelling in water. Wood Sci. Technol., 1994, 28, 119-134.

2. Siau, J. F. Wood: Influence of Moisture on Physical Properties. VPI, Virginia, 1995.

3. Mantanis, G. I., Young, R. A. and Rowell, R. M. Swelling of wood, II: Swelling in organic liquids. Holzforsch., 1994, 48, 480-490.

4. Bodig, J. and Jayne, B. A. Mechanics of Wood and Wood Composites. Van Nostrand Reinhold, New York, 1982.

5. Meier, P., Kaps, T. and Kallavus, U. Swelling of pinewood (Pinus Sylvestris) in aqueous solutions of organic substances. Mater. Sci. (Medziagotyra), 2005, 11, 140-145. 
6. Meier, P., Rohumaa, A., Kallavus, U. and Kaps, T. Multiple swelling of pinewood (Pinus Sylvestris) in binary and ternary mixtures of ethanol, acetone and water. Mater. Sci. (Medziagotyra). Forthcoming.

7. Ishimaru, Y., Narimoto, S. and Iida, I. Mechanical properties of wood swollen in organic liquids with two or more functional groups for hydrogen bonding in a molecule. J. Wood Sci., 2001, 47, 171-177.

8. Schneider, M. H., Sebastian, L. P. and Seepersad, J. Bending strength and stiffness of Caribbean pine from Trinidad and Tobago. Wood Fiber Sci., 1991, 23, 468-471.

9. Record, S. J. The Mechanical Properties of Wood. Including a Discussion of the Factors Affecting the Mechanical Properties, and Methods of Timber Testing. Project Gutenberg, Online Book Catalog, 2005.

10. Zhou, H. and Smith, I. Factors influencing bending properties of white spruce lumber. Wood Fiber Sci., 1991, 23, 483-499.

11. Wood Handbook - Wood as an Engineering Material. U.S. Department of Agriculture, Madisson, 2001.

12. Kretschmann, D. E. and Green, D. W. Modelling moisture content-mechanical property relationships for clear southern pine. Wood Fiber Sci., 1996, 28, 320-337.

\title{
Orgaanilistes ainetes pundunud puidu mehaanilised omadused
}

\author{
Pille Meier, Eve Stöör, Tiit Kaps ja Urve Kallavus
}

On uuritud vees, etanoolis, atsetoonis ja nende vesilahustes punnutatud männi maltspuidu mehaanilisi omadusi (tugevus staatilisel paindel ja survel piki puidukiude). Kõik katsed on teostatud olekus, kus puit on maksimaalselt pundunud. Kasutatud vedelikud on mõjutanud erinevalt nii puidu struktuuri kui ka mehaanilisi omadusi. On täheldatud puidu tugevusomaduste sõltuvust pundumisest. Vees, puhastes ainetes ja vesilahustes käitub puit erinevalt. Kõige suuremad muudatused on aset leidnud puidu pundumisel etanooli vesilahuses moolimurru 0,5 juures, kus pundumise käigus on rakud deformeerunud ja üksteisest täielikult eraldunud. Tugevusnäitajad on etanooli vesilahustes punnutatud puidul samaväärsed vee ja atsetooni vesilahuses punnutatud puiduga, kuid erinevus esineb puidu elastsusomadustes: punnutatud puidu läbipaine staatilisel paindekatsel on etanooli vesilahuse puhul suurem. 